\title{
PENGEMBANGAN MEDIA PEMBELAJARAN AKUNTANSI BERBASIS FILM DOKUMENTER UNTUK MENINGKATKAN MOTIVASI BELAJAR
}

\section{DEVELOPMENT OF ACCOUNTING LEARNING MEDIA BASED ON FILM DOCUMENTARY TO INCREASE LEARNING MOTIVATION}

\author{
Oleh: \\ Anindita Laksmi Suhita \\ Pendidikan Akuntansi Universitas Negeri Yogyakarta \\ nindadita26@gmail.com \\ Mahendra Adhi Nugroho \\ Staf Pengajar Jurusan P. Akuntansi Universitas Negeri Yogyakarta
}

\begin{abstract}
Abstrak
Penelitian ini bertujuan untuk: (1) mengembangkan media pembelajaran berbasis film dokumenter bagi siswa SMA kelas XII IPS dengan materi perusahaan dagang; (2) mengetahui kualitas media pembelajaran akuntansi berbasis film dokumenter berdasarkan penilaian oleh ahli materi, ahli media dan guru mata pelajaran akuntansi; serta (3) mengetahui peningkatan motivasi belajar akuntansi siswa sesudah menggunakan film dokumenter sebagai media pembelajaran akuntansi.Penelitian ini merupakan penelitian pengembangan (R\&D) model pengembangan ADDIE. Teknik pengumpulan data melalui angket. Hasil penelitian yaitu berdasarkan penilaian oleh ahli materi dari aspek materi memperoleh skor sebesar 2,7 termasuk dalam kategori baik, dan aspek pembelajaran memperoleh skor sebesar 3,6 termasuk dalam kategori sangat baik. Ahli media menilai media dari aspek tampilan memperoleh skor sebesar 3,8 termasuk dalam kategori sangat baik dan aspek pemrograman memperoleh skor sebesar 3,4 termasuk dalam kategori sangat baik. Sedangkan guru mata pelajaran akuntansi SMA menilai media dari aspek materi memperoleh skor sebesar 3,7 termasuk dalam kategori sangat baik, aspek pembelajaran memperoleh skor sebesar 3,0 termasuk dalam kategori sangat baik, dan aspek media memperoleh skor sebesar 3,7 termasuk dalam kategori sangat baik. Pada pengujian gain score memperoleh skor sebesar 0,44 dengan kategori sedang.
\end{abstract}

Kata Kunci: Media Pembelajaran Akuntansi, Film Dokumenter, Motivasi Belajar Akuntansi Siswa

\begin{abstract}
The focus of this research are to: (1) the development of learning media which based on film documentary for social science students in grade XII with trading company's materials; (2) to find out the quality of accounting learning media that based on film documentary according to the assessment of matter expert, media specialist, and accounting teachers; (3) to determine the increase of the students' motivation to learn accounting after employing film documentary as a learning media. This development research employs several procedures of Research and Development $(R \& D)$ which also adapts the model of ADDIE. Data collection techniques through the questionnaire. The results showed that the experts' assessment in the matter aspect got a score of 2.7. It is assumed to be good a result, learning aspect similarly has a very good score, 3.6. Media specialist gave the assessment of media in the aspect of display with a best score of 3.8. The programming aspect also showed a very good score of 3.4. Meanwhile the accounting teachers assessed the media of matter aspects with a very good score of 3.7. The other aspects that also got a very good score are learning aspects with 3.0 and media aspect with a score of 3.7. The increase of learning accounting motivation which employed questionnaire has a score of 0.44 , which is categorized into medium one.
\end{abstract}

Keywords: Accounting Learning Media, Film Documentary, Students Accounting Learning Motivatio 


\section{PENDAHULUAN}

Pendidikan merupakan salah satu kunci terbentuknya sumber daya manusia yang kompeten dalam membangun bangsa. Melalui pendidikan diharapkan dapat menciptakan generasi yang berguna untuk bangsa dan negara. Selain itu dengan pendidikan diharapkan pula dapat meningkatkan diri seseorang dalam segala aspek.

Menurut UU No. 20 Tahun 2003, pendidikan merupakan suatu usaha sadar dan terencana yang dilakukan oleh pendidik melalui bimbingan, pengajaran, dan latihan untuk mewujudkan suasana belajar dan proses pembelajaran agar siswa aktif yang mengarah pada tercapainya pribadi yang dewasa. Pendidikan selayaknya diselenggarakan secara demokratis sehingga menghasilkan pendidikan yang bermutu bagi setiap warga negara.

Adanya peran dan fungsi pendidikan yang penting maka perlu perbaikan mutu pendidikan secara terus menerus. Perbaikan ini meliputi proses dalam belajar mengajar. Sardiman A.M (2012: 13) menyatakan bahwa proses belajar mengajar merupakan proses kegiatan interaksi antara dua unsur manusiawi, yakni siswa sebagai pihak belajar dan guru sebagai pihak yang mengajar, dengan siswa sebagai subjek pokoknya.

Saat ini sering ditemukan proses pembelajaran di sekolah hanya menempatkan siswa sebagai objek yang selalu diberikan beragam materi dengan jumlah yang sangat banyak, sehingga banyak materi yang kurang dipahami dan cenderung dihafalkan oleh siswa. Dalam penyampaiannya, guru juga sering menggunakan metode ceramah sehingga dapat mengakibatkan siswa mengalami kebosanan dan akan berdampak pada motivasi siswa yang menurun. Guru pada umumnya kurang dapat memanfaatkan media yang sudah tersedia. Kegiatan belajar mengajar akhirnya akan berpusat kepada guru dan terjadi komunikasi satu arah.
Perkembangan teknologi informasi dan tuntutan globalisasi yang semakin besar saat ini tidak bisa dihindari lagi pengaruhnya terhadap dunia pendidikan. Kemajuan teknologi informasi yang sangat pesat mendorong pengembangan dan penciptaan hal-hal baru khususnya dalam proses pembelajaran dan media pembelajaran yang semakin interaktif dan inovatif.

Dalam implementasi pembelajaran di Sekolah Menengah Atas Negeri 1 Seyegan sudah menggunakan Kurikulum 2013. Menurut keterangan guru Akuntansi kelas XII IPS 3, menyatakan bahwa pada saat kegiatan belajar mengajar kurang dari $75 \%$ siswa dikelas yang memperhatikan penjelasan dari guru, banyak siswa tidak memperhatikan penjelasan guru, ada yang hanya mengobrol dengan teman sebangku, ada yang tidur dibelakang, dan ada beberapa siswa yang asyik dengan handphonenya. Menurut E. Mulyasa (2013: 218), pembelajaran dikatakan berhasil dan berkualitas apabila seluruhnya atau sebagian besar $(75 \%)$ siswa terlibat ssecara aktif, baik fisik, mental, maupun sosial dalam proses pembelajaran, disamping menunjukkan kegairahan belajar yang tinggi, semangat belajar yang besar, dan rasa percaya pada diri sendiri. Hal ini dapat diasumsikan faktor penyebabnya secara umum adalah faktor guru dan faktor dari siswa yang memiliki motivasi belajar terhadap akuntansi masih kurang.

Berdasarkan observasi di kelas XII IPS 3 pada saat pelaksanaan kegiatan Praktik Pengalaman Lapangan (PPL), asumsi tersebut mengarah pada cara guru dalam mentransfer ilmunya kurang menarik, karena guru dalam menjelaskan lebih ke arah berceramah dan terpaku pada buku teks dan slide powerpoint, sehingga banyak siswa yang terkadang merasa bosan sehingga mengalihkan perhatian ke hal lain. Selain kurangnya pemanfaatan media, guru juga lebih sering menganggap Lembar Kerja Siswa (LKS) merupakan media yang mudah digunakan dalam proses pembelajaran. Guru 
sebenarnya sudah menggunakan media power point, tetapi dalam menggunakan media tersebut kurang memberikan dampak yang menarik sehingga siswa tidak memiliki rasa ingin tahu yang tinggi, sehingga diperlukan media pembelajaran yang kreatif dan inovatif.

Berdasarkan hasil wawancara dengan guru mata pelajaran akuntansi, bahwa siswa kelas XII IPS 3 memiliki motivasi yang masih rendah pada mata pelajaran akuntansi. Siswa menganggap pelajaran akuntansi merupakan pelajaran yang sukar karena banyak teori dan praktek yang harus dihafalkan sehingga sulit untuk dipahami. Dalam hal ini maka guru perlu memberikan contoh yang mampu memvisualisasikan materi pelajaran akuntansi sehingga siswa dapat dengan mudah memahami, motivasi siswa meningkat, dan kegiatan belajar mengajar menjadi menarik dan menyenangkan.

Menurut Rusman M.Pd dkk, (2012: 170), media pembelajaran merupakan suatu teknologi pembawa pesan yang dapat digunakan oleh guru untuk keperluan pembelajaran; media pembelajaran merupakan sarana fisik untuk menyampaikan materi pelajaran. Media pembelajaran merupakan sarana komunikasi dalam bentuk cetak maupun pandang dengar termasuk teknologi perangkat keras. Media pembelajaran yang dapat digunakan saat ini seperti media teks, video, dan audio kemudian dengan adanya kemajuan teknologi maka berkembang lagi menjadi grafis, foto, dan animasi. Media yang berkembang saat ini digabungkan menjadi satu kesatuan yang akan menghasilkan informasi yang tidak hanya dapat dilihat sebagai cetakan, melainkan juga dapat didengar, membentuk simulasi, dan animasi yang dapat membangkitkan motivasi dalam penerimaannya. Salah satu contoh media pembelajaran gabungan adalah media pembelajaran berbasis film dokumenter.

Media pembelajaran berbasis film dokumenter merupakan salah satu inovasi media pembelajaran akuntansi. Media pembelajaran berbasis film dokumenter ini berbentuk film pendek yang berdurasi 5-15 menit. Film ini dipersiapkan khusus dengan memperhatikan sisi edukatif dan entertaint. Menurut Rebecca Anrini (2012) bahwa film juga merupakan salah satu media belajar dalam dunia pendidikan. Tak jarang karena pengaruh film, seorang anak berusaha menirukan adegan yang mereka lihat. Film tidak hanya untuk diperdagangkan namun diperhatikan untuk pendidikan. Film memberikan unsur kognitif berupa pemahaman materi melalui alur cerita dan tidak lupa pemberian pesan moral sebagai tambahan karakter bagi siswa.

Dengan demikian berdasarkan analisis situasi di SMA N I Seyegan, maka perlu pengembangan media pembelajaran berbasis film dokumenter. Film dokumenter dipilih karena relatif mudah dalam pembuatannya dan dapat menggambarkan keadaan senyatanya sehingga siswa dapat mempraktikkan di kehidupan nyata.

\section{METODE PENELITIAN Jenis Penelitian}

Penelitian ini merupakan jenis penelitian berupa penelitian dan pengembangan (Research and Development) yang diadaptasi dari model pengembangan ADDIE (Endang Mulyatiningsih. 2013:200)

\section{Waktu dan Tempat Penelitian}

Penelitian dilaksanakan di SMA N I Seyegan yang berada di dusun Tegal Gentan, Margoagung, Seyegan, Sleman, Yogyakarta sebagai tempat pelaksanaan uji coba. Penelitian ini akan dilaksanakan pada bulan November 2015 sampai dengan Januari 2016, sedangkan pada tahap pelaporan dilaksanakan pada bulan Februari-Maret 2016.

\section{Target/Subjek Penelitian}

Subyek penelitian adalah siswa kelas XII IPS 3 SMA Negeri 1 Seyegan tahun ajaran 2015/2016, sedangkan objek penelitiannya adalah media pembelajaran akuntansi berbasis film dokumenter. 
Prosedur

Pengembangan media film dokumenter merupakan media audio visual membutuhkan dua kegiatan yaitu perancangan tampilan media dan perancangan isi media. Perancangan isi media menurut Hackbarth, sebagaimana yang dikutip oleh Endang Mulyatiningsih (2011) meliputi tahap-tahap:

a. Memilih dan menyusun kerangka materi dan tujuan pembelajaran.

b. Mengorganisasikan isi dan merancang alur cerita secara umum

c. Menulis skrip yang berisi rancangan gambar, teks atau narasi film, tipe shooting, transisi gambar dan musik pengiring.

d. Merancang produksi film, mulai dari perancangan bahan dan alat, waktu pengambilan gambar dan tokoh-tokoh yang berperan.

Setelah media film selesai diproduksi, pengembang media masih perlu menguji tampilan media dan efektivitas media tersebut dalam proses pembelajaran. Pengujian pertama dilakukan oleh beberapa pakar media. Hal-hal yang diuji meliputi tampilan gambar, suara, dan isi yang termuat dalam film. Selama penggunaan media film dilakukan pengamatan respon peserta didik dalam melihat tayangan film. Sesudah penayangan film dilakukan pengukuran-pengukuran motivasi belajar sesuai dengan tujuan belajar yang ingin dicapai.

\section{Teknik Pengumpulan Data dan Instrumen Penelitian}

Penelitian ini menggunakan teknik pengumpulan data berupa angket. Instrumen penelitian angket diisi oleh ahli materi, ahli media, praktisi pembelajaran dan peserta didik.

\section{Teknik Analisis Data}

Data yang diperoleh dari angket dianalisis secara deskriptif kualitatif dan kuantitatif. Data kualitatif berupa kritik dan saran dari ahli materi, ahli media, dan guru akuntansi yang dihimpun untuk memperbaiki Media Pembelajaran Akuntansi Berbasis Film Dokumenter ini. Data kuantitatif yang dianalisis berasal dari:

a. Analisis Data Kuantitatif Penilaian Media

Mengacu pada konversi empat skala Djemari Mardapi (2008: 123) yaitu dengan cara menghitung rata-rata skor tiap indikator terlebih dahulu menggunakan rumus:

$$
\mathrm{X}=\frac{\sum x}{n}
$$

Keterangan:

$\mathrm{X}=$ skor rata-rata

$\sum \mathrm{X}=$ jumlah skor

$\mathrm{n}=$ jumlah penilai

b. peningkatan motivasi belajar siswa dapat diketahui dengan gain score. Gain score disebut juga dengan peningkatan atau perbedaan skor yang merupakan selisih antara skor angket awal dan skor angket akhir. Hasil dari analisis data gain score menunjukkan pencapaian peningkatan motivasi siswa. Dengan demikian hasil perhitungan gain score dapat mengetahui keefektifan hasil pengembangan film dokumenter terhadap pembelajaran. Perhitungan dapat dilakukan dengan cara:

Gain Score = $\frac{\text { skor angket akhir-s } \oplus \text { or angket awal }}{\text { skor maksimum-skor angket awal }}$

\section{HASIL PENELITIAN DAN}

\section{PEMBAHASAN}

Prosedur yang digunakan dalam pengembangan produk ini merupakan adaptasi dan dimodifikasi dari langkahlangkah penelitian dan pengembangan ADDIE. Penelitian meliputi lima tahap yaitu:

1. Tahap Analisis, berupa wawancara dengan guru mata pelajaran ekonomiakuntansi dan diperoleh beberapa informasi. Informasi tersebut yaitu tentang proses pembelajaran di kelas 
yang belum dapat memanfaatkan media pembelajaran secara optimal. Media pembelajaran yang sering digunakan guru antara lain buku paket, LKS, dan program powerpoint. Proses pembelajaran tersebut memberikan pengaruh pada motivasi belajar siswa menjadi rendah. Pengembangan media pembelajaran akuntansi berbasis film dokumenter ini bertujuan untuk meningkatkan motivasi belajar siswa pada mata pelajaran akuntansi. Dengan adanya media pembelajaran akuntansi berbasis film dokumenter ini siswa dapat memahami konsep-konsep akuntansi dengan mudah.

2. Tahap Perancangan meliputi perancangan desain produk yaitu menyusun kompetensi inti, kompetensi dasar, indikator dan materi yang akan dikembangkan dalam media pembelajaran akuntansi berbasis film dokumenter. Materi yang akan dikembangkan tentang perusahaan dagang dalam struktur silabus kurikulum 2013. Tahap selanjutnya adalah menyusun konsep film dokumenter.

3. Tahap Pengembangan meliputi pembuatan media; penilaian media meliputi:

a) Penilaian ahli materi pada aspek materi memperoleh skor 2,7 kategori baik dan aspek pembelajaran memperoleh skor 3,6 kategori sangat baik.

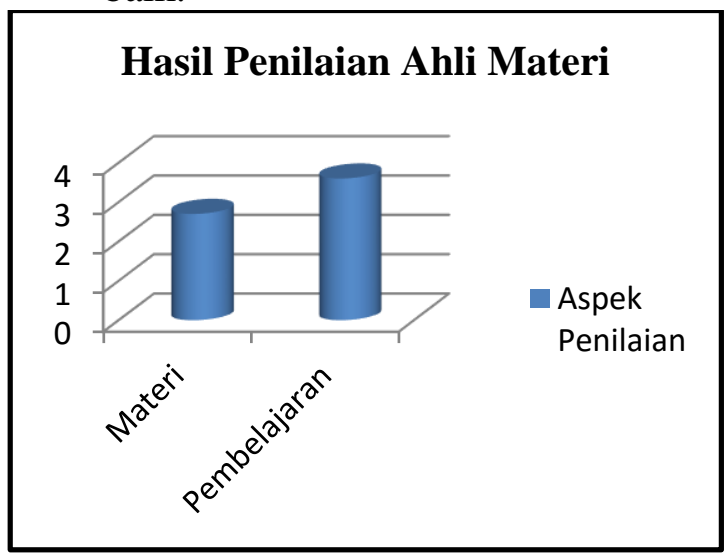

Gambar 1. Diagram Batang Hasil penilaian Ahli Materi b) Penilaian media oleh ahli media dari aspek tampilan memperoleh skor 3,8 dengan kategori sangat baik dan aspek pemrograman memperoleh skor 3,4 dengan kategori sangat baik.

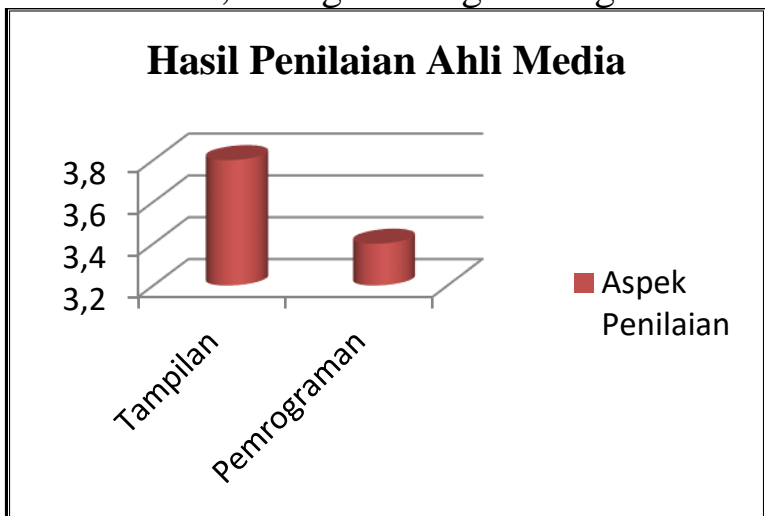

Gambar 2. Diagram Batang Hasil Penilaian Ahli Media

c) Penilaian oleh guru akuntansi SMA dari aspek materi dan media memperoleh skor sebesar 3,7 dengan kategori sangat baik, sedangkan untuk aspek pembelajaran memperoleh skor sebesar 3,0 dengan kategori sangat baik.

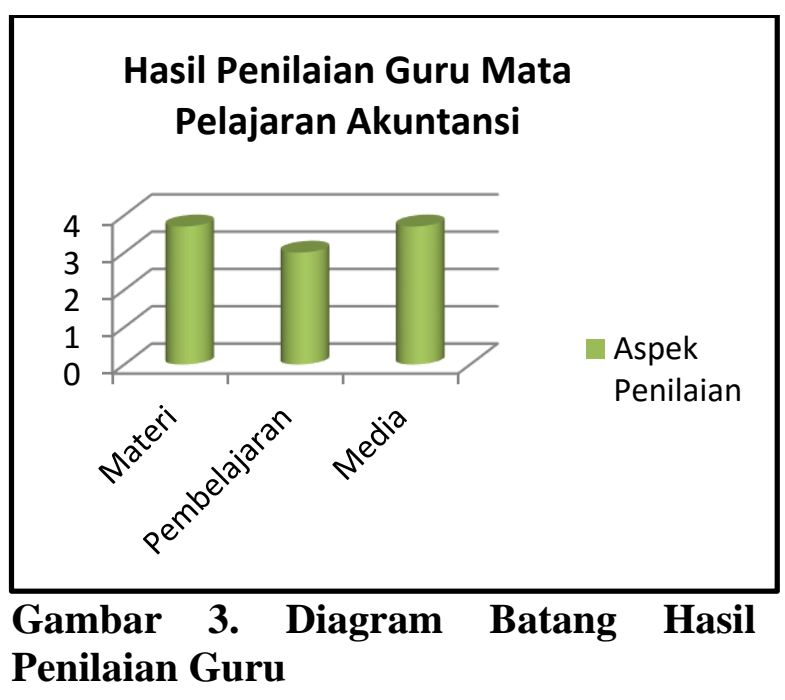

4. Tahap terakhir dari pengembangan yaitu revisi produk sesuai saran para ahli yaitu:

a) Revisi ahli materi yaitu perlu ditambahkan indikator pencapaian dalam film dokumenter 


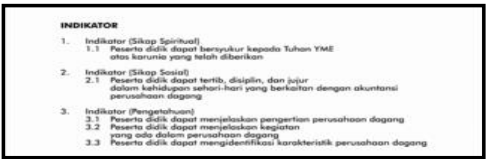

Gambar 4. Penambahan indikator pencapaian

b) Revisi ahli media antara lain:

Perubahan halaman pembuka film dokumenter

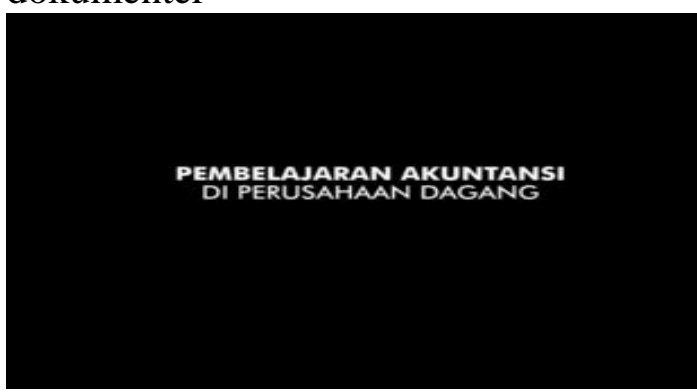

Gambar 5. Halaman pembuka film sebelum revisi

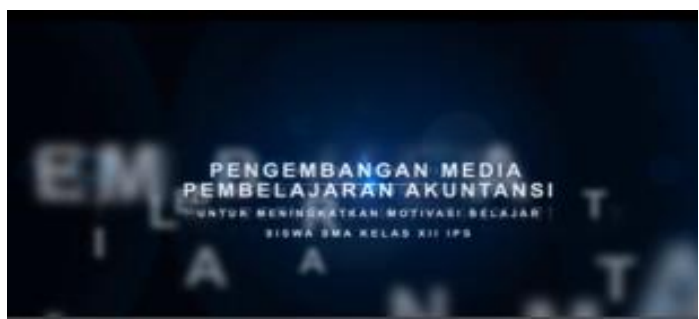

Gambar 6. Halaman pembuka film setelah revisi

Penambahan logo UNY pada film dokumenter

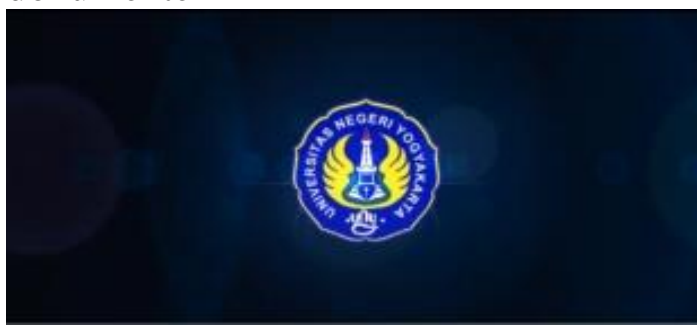

Gambar 7. Tambahan logo UNY setelah direvisi

Penambahan presenter sebagai pembuka dan penutup film

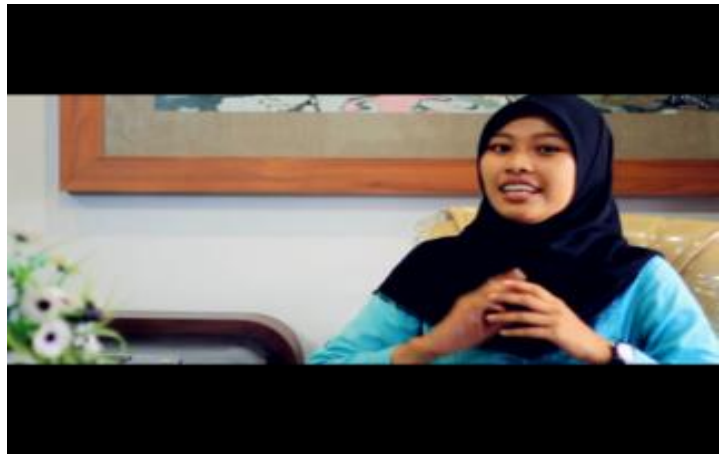

Gambar 8. Tambahan presenter sebagai pembuka film

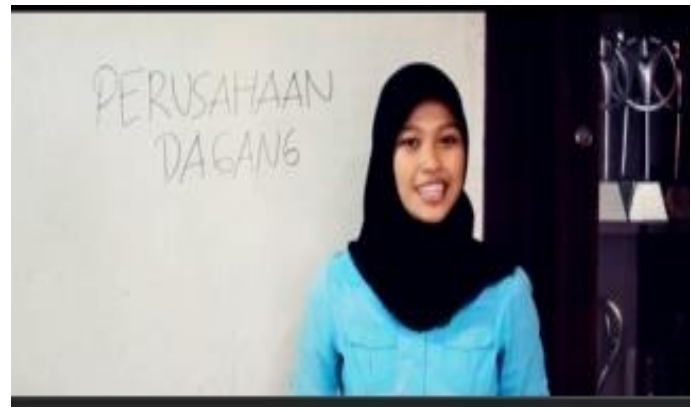

Gambar 9. Tambahan presenter sebagai penutup film

c) Revisi dari Guru Mata Pelajaran Akuntansi SMA

Adapun saran dan masukan yang diberikan oleh guru mata pelajaran akuntansi yaitu dalam pembuatan kesimpulan oleh presenter perlu ditekankan pada bagian karakteristik perusahaan dagang dan ditambahkan pemberian pertanyaan kepada siswa agar siswa dapat memberikan feedback terhadap materi dalam film dokumenter tersebut. Saran dari guru mata pelajaran akuntansi tersebut belum dapat terpenuhi karena keterbatasan peniliti untuk mengambil gambar kembali pada saat penyampaian kesimpulannya.

5. Tahap Implementasi

Pada tahap implementasi media pembelajaran akuntansi berbasis film dokumenter yang telah dikembangkan digunakan terlebih dahulu untuk menguji 
validitas dan reliabilitas instrumen motivasi belajar akuntansi belajar siswa berupa angket motivasi belajar akuntansi awal dan angket motivasi belajar akhir. Sebelum uji validitas dan reliabilitas dilakukan, masing-masing angket motivasi belajar akuntansi terdapat 19 butir pernyataan. Uji validitas dan reliabilitas instrumen dilaksanakan di luar sampel yaitu di kelas XII IPS 1 SMA N 1 Seyegan pada tanggal 3 februari 2016. Selama implementasi, film dokumenter perusahaan dagang telah diterapkan pada kondisi yang sebenarnya.

6. Tahap Evaluasi

Pada tahap ini kegiatan yang dilakukan adalah mengukur motivasi belajar akuntansi siswa dengan menggunakan media pembelajaran berbasis film dokumenter perusahaan dagang. Film dokumenter perusahaan dagang diproduksi dengan tujuan untuk meningkatkan motivasi belajar akuntansi kelas XII IPS 3 SMA N 1 Seyegan. Peningkatan motivasi belajar akuntansi diukur menggunakan lembar angket awal yaitu angket sebelum menggunakan media film dokumenter dan lembar angket akhir yaitu setelah menggunakan media film dokumenter. Angket yang digunakan yaitu angket dengan model penilaian skala likert. Berdasarkan hasil perhitungan diketahui bahwa rerata motivasi belajar akuntansi awal dan motivasi belajar akuntansi akhir adalah seperti pada tabel 1 .

Tabel 1. Skor Motivasi Belajar Awal Dan Skor Motivasi Belajar Akhir

\begin{tabular}{|c|c|}
\hline $\begin{array}{c}\text { Angket Motivasi } \\
\text { Belajar Akuntansi } \\
\text { Awal }\end{array}$ & $\begin{array}{c}\text { Angket Motivasi } \\
\text { Belajar Akuntansi } \\
\text { Akhir }\end{array}$ \\
\hline 1193 & 1435 \\
\hline
\end{tabular}

Sumber: Data Pengembangan Penelitian yang Diolah

Hasil pengukuran motivasi belajar akuntansi siswa dengan menggunakan
Gain score disajikan dalam diagram batang dapat dilihat pada gambar 10 .

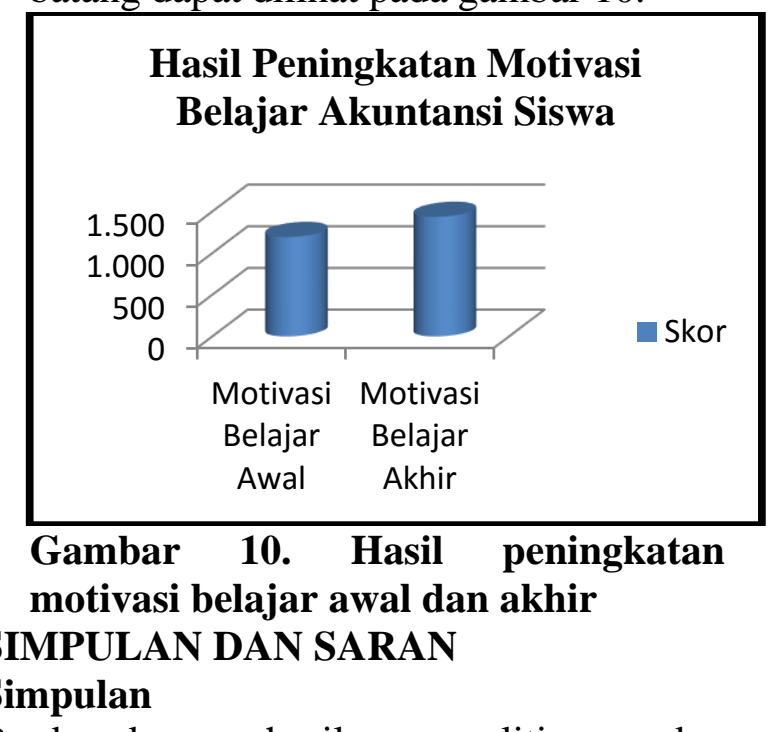

Berdasarkan hasil penelitian dan pembahasan, dapat disimpulkan bahwa:

a. Pengembangan media pembelajaran akuntansi berbasis film dokumenter melalui lima tahap yaitu:

1) Analysis, yaitu tahap awal pra produksi yang meliputi analisis kurikulum, analisis kebutuhan dan analisis tujuan pembelajaran.

2) Design, merupakan tahap pengumpulan data dan materi, pembuatan konsep yang meliputi pembuatan ringkasan cerita, naskah skenario, dan shooting script kemudian dilanjutkan pada tahap pengembangan media pembelajaran akuntansi berbasis film dokumenter.

3) Development, yaitu tahap melakukan penilaian dan evaluasi oleh ahli materi, ahli media, dan guru akuntansi SMA serta menganalisis hasil penilaian kemudian melakukan perbaikan/revisi produk untuk memperoleh produk akhir.

4) Implementation, merupakan tahap pengujian validitas dan reliabilitas instrumen motivasi belajar akuntansi siswa dengan menggunakan media pembelajaran akuntansi berbasis film dokumenter yang telah dikembangkan. 
5) Evaluate, merupakan tahap akhir untuk mengukur peningkatan motivasi belajar akuntansi siswa setelah menggunakan film dokumenter sebagai media pembelajaran akuntansi.

b. Hasil penilaian oleh ahli materi, penilaian media pembelajaran akuntansi berbasis film dokumenter dari aspek materi memperoleh skor sebesar 2,7 yang termasuk dalam kategori baik, demikian juga dengan aspek pembelajaran memperoleh skor sebesar 3,6 yang termasuk dalam kategori sangat baik. Ahli media menilai media dari aspek tampilan memperoleh skor sebesar 3,8 yang termasuk dalam kategori sangat baik dan aspek pemrograman memperoleh skor sebesar 3,4 yang termasuk dalam kategori sangat baik. Sedangkan guru mata pelajaran akuntansi SMA menilai media dari aspek materi memperoleh skor sebesar 3,7 yang termasuk dalam kategori sangat baik, aspek pembelajaran memperoleh skor sebesar 3,0 yang termasuk dalam kategori sangat baik, dan aspek media memperoleh skor sebesar 3,7 yang termasuk dalam kategori sangat baik. Kesimpulan dari penilaian media tersebut adalah bahwa media pembelajaran akuntansi berbasis film dokumenter baik digunakan dalam proses pembelajaran.

c. Media pembelajaran akuntansi berbasis film dokumenter terbukti mampu meningkatkan motivasi belajar dengan gain score sebesar 0,44 yang termasuk dalam kategori sedang.

\section{Saran}

Berdasarkan pembahasan hasil penelitian dan pengembangan media pembelajaran akuntansi berbasis film dokumenter, maka beberapa saran yang diajukan antara lain:

a. Perlu adanya pengembangan media pembelajaran yang bersifat dinamis dan dapat disesuaikan dengan perkembangan teknologi.Perlu adanya penelitian selanjutnya untuk dapat mengembangkan media pembelajaran akuntansi berbasis film dokumenter sehingga dapat menghasilkan media dengan materi yang lebih mendalam, interaktif dan dapat menarik perhatian siswa.

b. Untuk meningkatkan motivasi belajar dapat dilakukan dengan media pembelajaran. oleh karena itu, perlu adanya media pembelajaran yang inovatif, salah satunya dengan menggunakan media pembelajaran akuntansi berbasis film dokumenter.

c. Guru lebih baik menggunakan variasi media dalam proses pembelajaran untuk materi yang sulit divisualisasikan dengan verbal. Sehingga siswa dapat dengan mudah memahami konsep serta lebih meningkatkan motivasi belajar siswa.

\section{DAFTAR PUSTAKA}

Djemari Mardapi. 2008. Teknik Penyusunan Instrumen Tes dan Non Tes. Yogyakarta. Mitra Cendekia Press

E. Mulyasa. 2013. Implementasi Kurikulum Tingkat Satuan Pendidikan Kemandirian Guru dan Kepala Sekolah. Jakarta: Bumi Aksar.

Endang Mulyatiningsih. 2012. Metode Penelitian Terapan Bidang Pendidikan. Bandung: Alfabeta

Rebecca Anrini. 2012. Film Indonesia untuk Pendidikan Tidak Produk Dagang. Diambil dari edukasi.kompasiana.com. pada tanggal 28 April 2015

Rusman, dkk. 2012. Pembelajaran Berbasis Teknologi Informasidan Komunikasi. Jakarta: Rajawali Pers. 